\title{
Antioxidant activities of ethanol extracts of Aster scaber grown in wild and culture field
}

\author{
Guy-Min Kim ${ }^{1}$, Ju-Yeon Hong ${ }^{1}$, Sook-Yi Woo ${ }^{1}$, Hyun-Suk Lee ${ }^{1}$, Young-Jun Choi ${ }^{2}$, \\ Seung-Ryeul Shin ${ }^{1 *}$ \\ ${ }^{1}$ Faculty of Herbal Food Cuisine and Nutrition, Daegu Haany University, Gyeongsan 38578, Korea \\ ${ }^{2}$ Department of Food Nutrition and Culinary Arts, Daegu Technical University, Daegu 42734, Korea
}

\section{야생 및 재배 참취 에탄올 추출물의 항산화성}

\author{
김규민 ${ }^{1} \cdot$ 홍주연 $^{1} \cdot$ 우숙이 $^{1} \cdot$ 이현석 $^{1} \cdot$ 최영준 $^{2} \cdot$ 신승렬 $^{1 *}$ \\ ${ }^{1}$ 대구한의대학교 한방식품조리영양학부, ${ }^{2}$ 대구공업대학교 호텔외식조리계열
}

\begin{abstract}
The purpose of this study was to evaluate the functionality of ethanol extract of Aster scaber by analyzing anti-oxidant components and anti-oxidant activities, which was grown in wild and culture field. The yields of Aster scaber ethanol extracts were high after blanching treatment. The polyphenol content of dried Aster scaber grown in wild was $35.59 \mathrm{mg} / \mathrm{g}$, which was higher than that of Aster scaber grown in culture field. The electron donating ability in all Aster scaber extracts were increased with increase in extract concentration, and the electron donating ability was the highest in extracts of the dried Aster scaber after blanching. The SOD-like activity of Aster scaber was the highest in its extract grown in wild field. In addition, the SOD-like activities of extracts of the dired Aster scaber after blanching were highest among the extracts of cultivated Aster scaber. The nitrite scavenging ability of extracts was increased at $\mathrm{pH} \mathrm{1.2}$, and those was the highest in wild fresh Aster scaber. The inhibition effects on xanthine oxidase and tyrosinase were increased with increase in extract concentration, and the inhibition effects of extracts of Aster scaber in wild field were higher than those grown in culture field. Therefore, the consumption of Aster scaber would provide beneficiary effects due to its antioxidant activities and prevention of aging. The development of various processed food using Aster scaber will promote the consumption and its values.
\end{abstract}

Key words : Aster scaber, herb, medical plant, antioxidant, functionality, polyphenol

\section{서 론}

최근 들어 인간의 수명이 증가하고 건강에 대한 관심이 높아짐에 따라 식품의 생리적 기능성에 대한 연구가 활발히 진행되고 있다. 야생하는 산채는 그 동안 영양적인 면이나 기호적인 면에서 중요성이 인식되지 않았으나 차나 채소류 에서 항산화성, 항암성, 항진균성 등의 기능성이 알려짐에

*Corresponding author. E-mail : shinsr@dhu.ac.kr Phone : 82-53-819-1428, Fax : 82-53-819-1494

Received 15 April 2015; Revised 15 June 2015; Accepted 11 August 2015.

Copyright (c) The Korean Society of Food Preservation. All rights reserved.
따라 상용하던 식품뿐 아니라 야생 산채에 대해서도 기능성 의 측면에서 관심을 가지게 되었다(1). 산채는 비타민, 무기 질 및 섬유소가 풍부하고 지방과 단백질의 함량은 매우 낮은 식용 작물로서, $\beta$-carotene, ascorbic acid, 무기질 및 섬유소가 풍부하며, 오랜 옛날부터 그 특유의 맛과 향, 식생 활 습관, 계절감 등 다양한 이유로 부식으로서 이용되어 왔다(2,3). 또한 식품이 갖는 항산화 및 항암 등과 같은 효과 에 관심이 주목되면서 이들을 이용한 다양한 특수식품이 개발되고 있다(4). 최근 들어 발달된 과학기술을 바탕으로 이러한 천연소재의 유효성분을 확인하고, 이를 건강 유지, 치료보조제 및 치료제로 활용하려는 많은 연구들이 전 세계 적으로 활발히 진행되고 있다(5-9).

우리나라의 산야에는 3,000 여종의 고등식물이 있으며, 
이 중 유효성분이 과학적으로 규명된 야생식물을 약용자원 식물이라 하는데, 이 부류에 속하는 식물이 약 900여 종이 있고, 서양 의약이 들어오기 오래 전부터 식품, 약품 및 향장품으로 이용되어 왔다. 그 중에서도 산과 들에 자생하 는 산채류는 약용 작용이 있는 것이 많아 고대부터 의약이 나 식재료로 사용되어 왔다(10,11).

우리나라에서 자생하는 취나물의 종류는 곰취, 참취 (Aster scaber), 수리취, 정옥취 등 60여종에 이르며, 일반적 으로 식용으로 이용되는 취나물은 참취, 개미취, 각시취, 곰취, 미역취, 가얌취, 수리취 등이 재배의 주종을 이루는데 그 중에서 향기가 독특하고 수확량이 많은 참취, 미역취, 곰취 등이 재배되고 있다(12). 취나물은 우리나라 전국 각처 의 산야지에서 흔히 자생하며 농가에서 재배하기도 하는 국화과의 다년생 초본으로 백운초, 백산국, 동풍, 나물채, 암취 및 나물취라고도 한다(13).

취나물의 재배는 울릉도에서는 미역취를 양양 등 강원도 에서는 곰취, 참취 등을, 경북의 북부지역인 영양, 봉화, 청송 등지에서는 참취와 곰취 등이 재배되고 있다. 상주 등지에는 햇순나물인 두릅, 가죽, 오가피순 등을 재배하여 농가소득 증대와 더불어 소비자에게 다양한 봄나물을 제공 하고 있다. 최근 성인병 예방과 무공해 건강식품에 대한 요구증가로 소비량도 증가하고 있는 추세이다(14).

현재 산채자원의 경우 대부분 생채 혹은 건조 산채의 단순가공식품으로만 생산 유통되어 왔기 때문에 시장규모 및 산업화 가능성에 대한 정보가 거의 전무한 실정이다. 산채는 식이섬유를 다량 함유하고 있기 때문에 항비만 및 지질대사에 도움이 되는 것으로 알려져 있으며 식이섬유 이외에도 다양한 건강증진효능을 가진 생리활성성분을 많 이 함유하고 있어 우수한 건강증진식품소재로서의 가능성 을 가지고 있다(15). 따라서 현재 산채자원의 산업화와 소비 증진을 이루기 위해서는 산채자원의 건강증진효능에 대한 과학적인 방법에 의한 검증 뿐 아니라 대량생산 및 가공유 통을 위한 기술이 절실하게 필요한 실정이다.

본 연구는 재배 및 건조방법에 따른 참취의 항산화성 물질의 분석 및 함량에 대하여 조사하고 전처리 방법에 따른 참취 에탄올 추출물의 항산화 활성에 대하여 조사하였 다.

\section{재료 및 방법}

\section{재 료}

본 연구의 주재료인 참취(Aster scaber)는 2012년 5월에 경북 영양군 영양읍 수비면에서 참취를 직접 채취하였으 며, 채취한 참취는 이물질을 제거 및 세척한 후 일정량으로 분취하여 초저온냉동기(MDF-U52V, Sanyo, Osaka, Japan) 에 보관하면서 시료로 사용하였다. 시료의 전처리 방법은
야생 참취와 재배한 참취를 생채와 자연건조, 블랜칭 건조 로 나누어 처리하였다. 생채 참취는 건조하지 않은 야생 생채 참취(WRA)와 재배 생채 참취(CRA)로 구분하였다. 참취의 자연건조는 영양군 농민들 이용하는 방법에 따라 그늘에서 수분 함량이 $30 \%$ 이하 되도록 건조하였으며, 야생 자연건조 참취는 $\mathrm{WRDA}$, 재배 자연건조 참취는 $\mathrm{CRDA}$ 로 표시하였다. 그리고 조는 참취를 $100^{\circ} \mathrm{C}$ 의 끓는 물에서 20 분 블랜칭 처리하고 자연건조하여 야생 및 재배 블랜칭 건조 참취를 각각 $\mathrm{WBDA}, \mathrm{CBDA}$ 로 표시하였다.

\section{추출물의 제조}

참취의 에탄올 추출물은 각 시료에 10 배의 $70 \%$ 에탄올을 가한 후 $50^{\circ} \mathrm{C}$ 에서 3 시간 동안 환류 추출하였다. 이 과정을 3회 반복 추출하여 모아진 추출액을 여과지(Whatman No. 2)로 여과하여 제조하였다. 추출액은 회전식감압증발 농축 기(R-210, BUCHI, Kyudo, Japan)를 사용하여 감압농축 하 였고, 동결건조기(FD8512, Ilshin, Seoul, Korea)로 $-90^{\circ} \mathrm{C}$ 에 서 동결 건조한 후 플라스틱용기에 담아서 초저온냉동기 (MDF-U52V, Sanyo, Osaka, Japan)에 보관하면서 추출물을 이용한 기능성 실험을 위한 시료로 사용하였다. 그리고 시 료의 추출 수율은 추출 전 시료 중량에 대한 추출물의 동결 건조 후의 중량 백분율로 나타내었다.

\section{총 폴리페놀 정량}

폴리페놀 화합물의 함량은 Folin-Denis법(16)으로 측정 하였다. 즉, 야생 및 재배 참취 추출물을 $10 \mathrm{mg} / \mathrm{mL}$ 의 농도로 증류수에 녹인 다음 $0.2 \mathrm{~mL}$ 를 시험관에 취하고 증류수를 가하여 $2 \mathrm{~mL}$ 로 만든 후 여기에 $0.2 \mathrm{~mL}$ Folin-Ciocalteu's phenol reagent를 첨가하여 잘 혼합한 후 3 분간 실온에 방치 하였다. 정확히 3 분 후 $\mathrm{Na}_{2} \mathrm{CO}_{3}$ 포화용액 $0.4 \mathrm{~mL}$ 를 가하여 혼합하고 증류수를 첨가하여 $4 \mathrm{~mL}$ 로 만든 후 실온에서 1시간 방치하여 흡수분광광도계(UV-2001, Hitachi, Tokyo, Japan)를 이용하여 $725 \mathrm{~nm}$ 에서 흡광도를 측정하였다. 이때 총 폴리페놀 화합물은 tannic acid(Sigma Chemical Co., USA)를 이용하여 작성한 표준곡선으로부터 산출하였다.

\section{총 플라보노이드 정량}

플라보노이드 함량은 Moreno 등이 행한 방법(17)에 따라 야생 및 재배참취 추출물을 $10 \mathrm{mg} / \mathrm{mL}$ 농도로 증류수에 녹 인 시료 용액 $0.1 \mathrm{~mL}$ 를 취하여 $10 \%$ aluminum nitrate와 $1 \mathrm{M}$ potassium acetate를 함유하는 $80 \%$ ethanol $4.3 \mathrm{~mL}$ 에 혼합하여 실온에서 40 분간 정치 한 후 흡수분광광도계 (UV-2001, Hitachi, Tokyo, Japan)를 이용하여 $415 \mathrm{~nm}$ 에서 흡광도를 측정하였다. 총 플라보노이드 정량은 quercetin (Sigma Chemical Co., USA)을 이용하여 작성한 표준곡선으 로부터 산출하였다. 


\section{전자공여능 측정}

전자공여능은 Blois 등의 방법(18)에 준하여 각 시료의 1,1-diphenyl-2-picryl hydrazyl(DPPH)에 대한 전자공여 효 과로써 시료의 환원력을 측정하였다. 즉 각 추출물을 농도 별로 제조한 시료 $2 \mathrm{~mL}$ 에 $0.2 \mathrm{mM} \mathrm{DPPH}$ 용액 $1 \mathrm{~mL}$ 를 가하 고, 10 초간 vortex mixing 후 $37^{\circ} \mathrm{C}$ 에서 30 분간 반응시킨 다음 이 반응액을 분광광도계(U-2001, Hitachi, Tokyo, Japan)를 사용해서 $517 \mathrm{~nm}$ 에서 흡광도를 측정하였다.

대조구는 천연 항산화제인 L-ascorbic acid를 사용하였 고, 아래와 같이 시료첨가구와 무첨가구의 흡광도의 차이 를 백분율(\%)로 표시하여 전자공여능으로 나타내었다.

Electron donating ability $(\%)=[1-(\mathrm{S}-\mathrm{B}) / \mathrm{C}] \times 100$

$\mathrm{S}$ : Sample 첨가구의 흡광도

$\mathrm{B}$ : Blank의 흡광도

$\mathrm{C}$ : Control(시료 무첨가구)의 흡광도

\section{SOD 유사활성 측정}

SOD 유사활성 측정은 Marklund 등의 방법(19)에 따라 각 시료 $0.2 \mathrm{~mL}$ 에 $\mathrm{pH} 8.5$ 로 보정한 tris- $\mathrm{HCl}$ buffer $(50 \mathrm{mM}$ tris[hydroxymethyl] amino-methane $+10 \mathrm{mM}$ EDTA) $3 \mathrm{~mL}$ 와 $7.2 \mathrm{mM}$ pyrogallol $0.2 \mathrm{~mL}$ 를 가하였다. 그런 다음 $25^{\circ} \mathrm{C}$ 에 서 10 분간 반응시킨 후 $1 \mathrm{~N} \mathrm{HCl} 0.1 \mathrm{~mL}$ 로 반응을 정지시키 고 $420 \mathrm{~nm}$ 에서 흡광도를 측정하였다. SOD 유사활성은 시 료 첨가구와 무첨가구 사이의 흡광도 감소율로 산출하였 다.

SOD 유사활성은 시료 첨가구와 시료 무첨가구 사이의 흡광도의 감소율로 아래와 같이 환산하였으며, 대조구로는 L-ascorbic acid를 사용하였다.

SOD like activity $(\%)=[1-(\mathrm{S}-\mathrm{B}) / \mathrm{C}] \times 100$

S : Sample의 흡광도

$\mathrm{B}$ : Blank의 흡광도

C : Control(시료 무첨가구)의 흡광도

\section{아질산염 소거능 측정}

아질산염 소거능은 Kato 등의 방법(20)에 따라 다음과 같이 측정하였다. 즉 $1 \mathrm{mM}$ 의 $\mathrm{NaNO}_{2}$ 용액 $2 \mathrm{~mL}$ 에 각 농도의 시료 $1 \mathrm{~mL}$ 를 첨가하고, 여기에 $0.1 \mathrm{~N} \mathrm{HCl}(\mathrm{pH} 1.2)$ 과 0.1 $\mathrm{M}$ 구연산 완충용액을 사용하여 반응용액의 $\mathrm{pH}$ 를 1.2 로 조정한 후 반응용액의 부피를 $10 \mathrm{~mL}$ 로 하였다. 그리고 37 ${ }^{\circ} \mathrm{C}$ 에서 1 시간 동안 반응시켜 얻은 반응액을 $1 \mathrm{~mL}$ 씩 취하고 여기에 $2 \%$ acetic acid $5 \mathrm{~mL}$ 를 첨가한 다음 Griess reagent $0.4 \mathrm{~mL}$ 를 가하여 혼합시켰다. 그런 다음 실온에서 15 분간 방치시킨 후 분광광도계(U-2001, Hitachi, Japan)를 사용하 여 $520 \mathrm{~nm}$ 에서 흡광도를 측정하여 잔존하는 아질산염의 백분율 $(\%)$ 로 나타내었다.
$\mathrm{pH} 1.2,3.0$ 에서 추출물의 농도에 따른 아질산염 분해 작용은 $1 \mathrm{mM}$ 의 $\mathrm{NaNO}_{2}$ 용액 $1 \mathrm{~mL}$ 에 각 농도의 각 추출물을 첨가하고 여기에 $0.1 \mathrm{~N} \mathrm{HCl}$ 을 사용하여 반응용액의 $\mathrm{pH}$ 를 $1.2,3.0$ 으로 조정한 후 반응용액의 부피를 $10 \mathrm{~mL}$ 로 하여 측정하였다.

무첨가구 L-ascorbic acid를 추출물의 농도와 동일하게 조제하여 사용하였고, 공시험은 Griess reagent 대신 증류수 $0.4 \mathrm{~mL}$ 를 가하여 같은 방법으로 행하였다.

Nitrite scavenging ability $(\%)=[1-(\mathrm{S}-\mathrm{B}) / \mathrm{C}] \times 100$

S : Sample의 흡광도

$\mathrm{B}$ : Blank의 흡광도

C : Control(시료 무첨가구)의 흡광도

\section{Xanthine oxidase 저해효과 측정}

Xanthine oxidase 저해효과는 Stripe와 Corte의 방법(21) 에 따라 측정하였다. 즉, 각 시료용액 $0.1 \mathrm{~mL}$ 와 $0.1 \mathrm{M}$ potassium phosphate buffer(pH 7.5) $0.6 \mathrm{~mL}$ 에 xanthine(2 $\mathrm{mM}$ )을 녹인 기질액 $0.2 \mathrm{~mL}$ 를 첨가하고 xanthine oxidase $(0.2 \mathrm{unit} / \mathrm{mL}) 0.1 \mathrm{~mL}$ 를 가하여 $37^{\circ} \mathrm{C}$ 에서 5 분간 반응시킨 후 $1 \mathrm{~N} \mathrm{HCl} 1 \mathrm{~mL}$ 를 가하여 반응을 종결하였다. 그리고 반응액에 생성된 uric acid의 양을 분광광도계(U-2001, Hitachi, Japan) $292 \mathrm{~nm}$ 에서 흡광도를 측정하였다. Xanthine oxidase 저해 효과는 시료용액의 첨가군과 무첨가군의 흡광 도 감소율로 나타내었다.

Xanthine oxidase 저해효과는 시료 첨가구와 시료 무첨가 구 사이의 흡광도의 감소율로 아래와 같이 환산하였으며, 대조구로는 천연 항산화제인 L-ascorbic acid를 사용하였다.

Xantine oxidase inhibition $(\%)=[1-(\mathrm{S}-\mathrm{B}) / \mathrm{C}] \times 100$

S : Sample의 uric acid 생성량

$\mathrm{B}$ : Blank의 흡광도

$\mathrm{C}$ : $\operatorname{Control}($ 시료 무첨가구)의 uric acid 생성량

\section{Tyrosinase 저해효과 측정}

Tyrosinase 저해효과 측정은 Yagi 등의 방법(22)에 따라 행하였다. 반응구는 $0.175 \mathrm{M}$ sodium phosphate buffer( $\mathrm{pH}$ 6.8) $0.5 \mathrm{~mL}$ 에 혼합액에 mushroom tyrosinase $(110 \mathrm{unit} / \mathrm{mL})$ $0.2 \mathrm{~mL}$ 을 첨가하여 $25^{\circ} \mathrm{C}$ 에서 2 분간 반응시켜 분광광도계 (U-2001, Hitachi, Japan)로 $475 \mathrm{~nm}$ 에서 측정하였다.

Tyrosinase 저해효과는 시료 첨가구와 시료 무첨가구 사 이의 흡광도의 감소율로 아래와 같이 환산하였으며, 대조 구 L-ascorbic acid를 사용하였다.

Tyrosinase inhibition $(\%)=[1-(\mathrm{S}-\mathrm{B}) / \mathrm{C}] \times 100$

$\mathrm{S}$ : Sample의 흡광도

$\mathrm{B}$ : Blank의 흡광도

C : Control(시료 무첨가구)의 흡광도 


\section{환원력 측정}

추출물의 환원력은 Wong과 Chye의 방법(23)을 일부 변 형하여 측정하였다. 각 시료용액 $0.5 \mathrm{~mL}$ 에 $0.2 \mathrm{M}$ phosphate buffer(pH 6.6) $1 \mathrm{~mL}$ 와 $1 \%$ potassium ferricyanide $1 \mathrm{~mL}$ 를 넣은 다음 잘 혼합하고 $50^{\circ} \mathrm{C}$ 에서 30 분간 반응시킨 후 실온 으로 냉각시켜 $10 \% \mathrm{TCA}$ 용액 $1 \mathrm{~mL}$ 를 넣은 다음 10 분간 방치하였다. 이 중 $0.5 \mathrm{~mL}$ 를 취해 증류수 $1 \mathrm{~mL}$ 와 $0.1 \%$ $\mathrm{FeCl}_{3} 0.5 \mathrm{~mL}$ 를 가한 후 분광광도계(U-2001, Hitachi, Japan) 로 $700 \mathrm{~nm}$ 에서 흡광도를 측정하였다. 환원력은 흡광도의 측정값으로 나타내었으며, 대조구로는 BHT(butyl hydroxy toluene, Sigma Aldrich Co., USA)를 사용하였다.

\section{통계처리}

$\operatorname{Park}(24)$ 의 방법을 응용하여 모든 실험은 3회 이상 반복 실시하였고, 평균 표준편차로 표시하였다. 각 실험결과는 SPSS 통계프로그램(18.0, SPSS Inc, Chicago, IL, USA)을 이용하여 일원배치 분산분석 one-way ANOVA와 Duncan's multiple range test 실시하여 $\mathrm{p}<0.05$ 에서 유의성을 검증하 고, 분석하였다.

\section{결과 및 고찰}

\section{추출물의 수율}

야생 및 재배의 생채, 자연건조 및 블랜칭 건조 참취에 $70 \%$ 에탄올 추출물의 수율을 측정한 결과는 Table 1 과 같다.

야생 생채, 자연건조 및 블랜칭 건조 참취에 $70 \%$ 에탄올 추출물의 수율을 측정한 결과 각각 $3.03,3.97,5.88 \%$ 으로 생채 참취에서 가장 수율이 낮았고, 블랜칭 건조 참취의 수율이 가장 높았다. 재배 생채, 자연건조 및 블랜칭 건조 참취에 에탄올 추출물의 수율은 각각 $3.46,4.39,5.02 \%$ 으로 야생 참취와 같이 생채 참취에서 수율이 가장 낮았고, 블랜 칭 건조 참취의 수율이 가장 높았다, 또한 재배 참취의 $70 \%$

Table 1. Yield of ethanol extracts from Aster scaber

$(\%)$

\begin{tabular}{cc}
\hline Samples $^{1)}$ & Yield \\
\cline { 2 - 2 } & Ethanol extract \\
\hline WRA & 3.03 \\
WRDA & 3.97 \\
WBDA & 5.88 \\
\hline CRA & 3.46 \\
CRDA & 4.39 \\
CBDA & 5.02 \\
\hline
\end{tabular}

${ }^{11}$ WRA, Aster scaber grow in the wild; WRDA, Aster scaber grow in the wild, and dried at $25^{\circ} \mathrm{C}$; WBDA, Aster scaber grow in the wild, and dried at $25^{\circ} \mathrm{C}$ after blanching; CRA, Aster scaber cultivated in the farm field; CRDA, Aster scaber cultivated in the farm field, and dried at $25^{\circ} \mathrm{C}, \mathrm{CBDA}$; Aster scaber cultivated in the farm field, and dried at $25^{\circ} \mathrm{C}$ after blanching.
에탄올 추출물의 수율이 야생 참취의 수율보다 높았다.

\section{총 폴리페놀 및 플라보노이드 함량}

식물계에 널리 분포되어 있는 2 차 대사산물인 페놀성 화합물은 분자 내 phenolic hydroxyl기가 효소 단백질과 같 은 거대 분자들과 결합하여 생리활성 기능을 나타내는 것으 로 알려져 있다(25). 항산화 활성과 관련되어 생체 내 산소 free radical 반응이 생체조직의 노화나 질병에 영향을 미치 며, 다양한 페놀성 물질들은 이러한 free radical 소거능이 우수하다고 보고되고 있다(26).

야생 및 재배 생채, 자연건조 및 블랜칭 건조 참취에 $70 \%$ 에탄올 추출물의 총 폴리페놀 함량 및 플라보노이드 함량을 측정한 결과는 Table 2 와 같다.

참취의 $70 \%$ 에탄올 추출물의 야생 생채 참취의 총 폴리 페놀 함량은 $16.30 \mathrm{mg} / \mathrm{g}$ 이었고, 자연건조 $22.66 \mathrm{mg} / \mathrm{g}$, 블랜 칭 건조 $35.59 \mathrm{mg} / \mathrm{g}$ 으로 블랜칭 건조 참취에서 높은 폴리페 놀 함량을 보였다. 재배 생채 참취의 총 폴리페놀 함량은 $18.34 \mathrm{mg} / \mathrm{g}$ 이었고, 자연건조 $24.38 \mathrm{mg} / \mathrm{g}$, 블랜칭 건조 26.83 $\mathrm{mg} / \mathrm{g}$ 으로 블랜칭 건조 참취에서 높은 폴리페놀 함량을 보 였다.

야생 및 재배 참취의 $70 \%$ 에탄올 추출물의 플라보노이드 함량 측정 결과 야생 생채 참취의 총 플라보노이드 함량은 $8.12 \mathrm{mg} / \mathrm{g}$ 이었고, 자연건조 참취 $5.01 \mathrm{mg} / \mathrm{g}$, 블랜칭 건조 참취 $9.37 \mathrm{mg} / \mathrm{g}$ 으로 블랜칭 건조 참취에서 높은 플라보노이 드 함량을 보였다. 재배 생채 참취의 총 플라보노이드 함량 은 $6.13 \mathrm{mg} / \mathrm{g}$ 이었고, 자연건조 참취 $5.59 \mathrm{mg} / \mathrm{g}$, 블랜칭 건조 참취 $9.00 \mathrm{mg} / \mathrm{g}$ 으로 블랜칭 건조 참취에서 높은 플라보노이 드 함량을 보였다.

Choi 등(27)은 참취 추출물의 총 폴리페놀 함량이 57.07 $\mu \mathrm{g} / \mathrm{mg}$ 함유하고 있다고 보고하였으며, Jeon 등(28)은 강원 도 지역에서 재배된 참취 추출물의 총 폴리페놀 화합물의

Table 2. Polyphenol and flavonoid contents of ethanol extracts from Aster scaber

\begin{tabular}{ccc}
\hline & & \\
\hline Samples $^{1)}$ & Polyphenols & Flavonoids \\
\hline WRA & $\left.16.30 \pm 0.05 \mathrm{f}^{2}\right)$ & $8.12 \pm 0.05 \mathrm{c}$ \\
WRDA & $22.66 \pm 0.14 \mathrm{~d}$ & $5.01 \pm 0.06 \mathrm{f}$ \\
WBDA & $35.59 \pm 0.09 \mathrm{a}$ & $9.37 \pm 0.07 \mathrm{a}$ \\
\hline CRA & $18.34 \pm 0.02 \mathrm{e}$ & $6.13 \pm 0.04 \mathrm{~d}$ \\
CRDA & $24.38 \pm 0.02 \mathrm{c}$ & $5.59 \pm 0.01 \mathrm{e}$ \\
CBDA & $26.83 \pm 0.03 \mathrm{~b}$ & $9.00 \pm 0.05 \mathrm{a}$
\end{tabular}

${ }^{1)}$ WRA, Aster scaber grow in the wild; WRDA, Aster scaber grow in the wild, and dried at $25^{\circ} \mathrm{C}$; WBDA, Aster scaber grow in the wild, and dried at $25^{\circ} \mathrm{C}$ after blanching; CRA, Aster scaber cultivated in the farm field; CRDA, Aster scaber cultivated in the farm field, and dried at $25^{\circ} \mathrm{C}$, CBDA; Aster scaber cultivated in the farm field, and dried at $25^{\circ} \mathrm{C}$ after blanching.

${ }^{2)}$ All values are expressed as mean $\pm \mathrm{SD}$ of triplicate determinations. Different letters indicate significantly different at $\mathrm{p}<0.05$ by Duncan's multiple range test. 
함량이 $99.60 \mu \mathrm{g} / \mathrm{mg}$ 로 나타나, 본 연구결과보다 더 높은 함량을 보였고, Lee 등(29)의 국내산 총 34종의 산채류에서 조제된 열수추출물의 폴리페놀 함량은 $4.6 ~ 183.8 \mathrm{mg} / \mathrm{g}$ 으로 매우 다양한 값을 보였는데, 이는 참취 및 각 산채류의 재배 조건, 추출 조건 및 실험 방법 등에 따른 함량 변이가 있음을 짐작해 볼 수 있으며, 항산화 성분이 지역별로 차이가 있기 때문인 것으로 생각된다.

\section{전자공여능}

야생 및 재배의 생채, 자연건조, 블랜칭 건조 참취의 $70 \%$ 에탄올 추출물의 항산화 활성 정도를 측정하고자 농도별 1,1- diphenyl-2-picryl hydrazyl(DPPH)에 대한 전자공여능 을 측정한 결과는 Fig. 1,2 와 같으며, 대조구로서는 천연 항산화제인 ascorbic acid를 사용하였다.

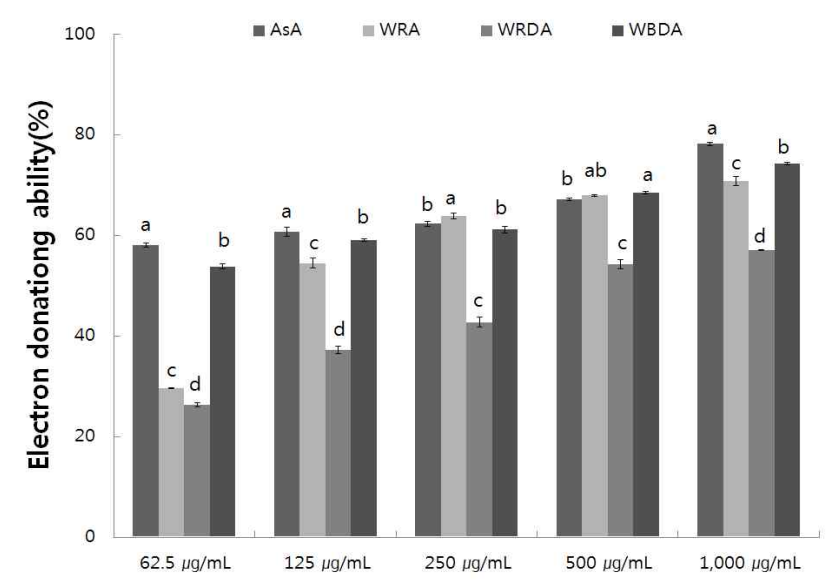

Fig. 1. Electron donating ability of ethanol extracts from Aster scaber in the wild.

WRA, Aster scaber grow in the wild; WRDA, Aster scaber grow in the wild, and dried at $25^{\circ} \mathrm{C}$; WBDA, Aster scaber grow in the wild, and dried at $25^{\circ} \mathrm{C}$ after blanching. All values are expressed as mean \pm SD of triplicate determinations. Different letters indicate significantly different at $p<0.05$ by Duncan's multiple range test.

야생 생채, 자연건조 및 블랜칭 건조 참취의 $70 \%$ 에탄올 추출물에 대한 전자공여능 측정 결과는 Fig. 1 과 같다. 야생 생채, 자연건조, 블랜칭 건조 참취의 에탄올 추출물의 전자 공여능은 농도가 증가함에 따라 증가하였다. $1,000 \mathrm{\mu g} / \mathrm{mL}$ 의 농도에서 블랜칭 건조 참취의 에탄올 추출물은 $74.31 \%$ 의 전자공여능을 보였으며, $62.5 \mathrm{\mu g} / \mathrm{mL}$ 농도에서 $53.77 \%$ 의 전자공여능을 보였고, 대조구인 천연 항산화제 ascorbic acid가 $62.5 \mathrm{\mu g} / \mathrm{mL}$ 농도에서 $57.99 \%$ 의 전자공여능을 보인 결과에 비하면 블랜칭 건조 참취 추출물은 낮은 농도에서도 높은 전자공여능을 나타냄으로서 블랜칭 건조의 에탄올 추출물의 기능성이 우수함을 알 수 있었다.

재배 생채, 자연건조, 블랜칭 건조 참취의 $70 \%$ 에탄올 추출물에 대한 전자공여능을 측정한 결과는 Fig. 2 와 같다. 재배 생채, 자연건조, 블랜칭 건조 참취의 에탄올 추출물은 농도가 증가함에 따라 추출물 모두 전자공여능이 증가함을
알 수 있었고, 야생 생채, 자연건조, 블랜칭 건조 참취의 에탄올 추출물의 전자공여능 측정 결과와 비슷하게 블랜칭 건조 참취 추출물에서 높은 전자공여능을 보였다. $500 \mu$ $\mathrm{g} / \mathrm{mL}$ 농도에서는 블랜칭 건조 참취 에탄올 추출물 $68.90 \%$ 의 전자공여능을 보여 대조구인 ascorbic acid보다 높은 전 자공여능을 보였다. 또한, 재배 생채 및 자연건조 참취의 에탄올 추출물 $500 \mathrm{\mu g} / \mathrm{mL}$ 농도에서는 각각 $50 \%$ 이상의 전 자공여능을 보여 블랜칭 건조 참취와 함께 생채 및 자연건 조 참취 추출물도 기능성이 우수할 것으로 생각된다. 따라 서 야생 및 재배 참취 에탄올 추출물의 전자공여능은 농도 가 증가함에 따라 전자공여능도 우수하였으며, 특히 블랜 칭 건조 참취의 추출물에서 높은 전자공여능을 확인 할 수 있었다.

Choi 등(27)의 참취 추출물의 항산화 활성 연구에서 농도 의존적으로 DPPH radical을 소거하여 본 연구결과와 유사 하였다. Free radical을 환원시키거나 상쇄시키는 능력이 크면 높은 항산화 활성 및 활성산소를 비롯한 다른 라디칼 에 대한 소거활성을 기대할 수 있으며, 인체 내에서 free radical에 의한 노화를 억제하는 척도로도 이용될 수 있으므 로(30), 본 연구의 야생 및 재배 참취 추출물은 전자공여능 이 높게 나타나 항산화력이 우수함을 알 수 있었다.

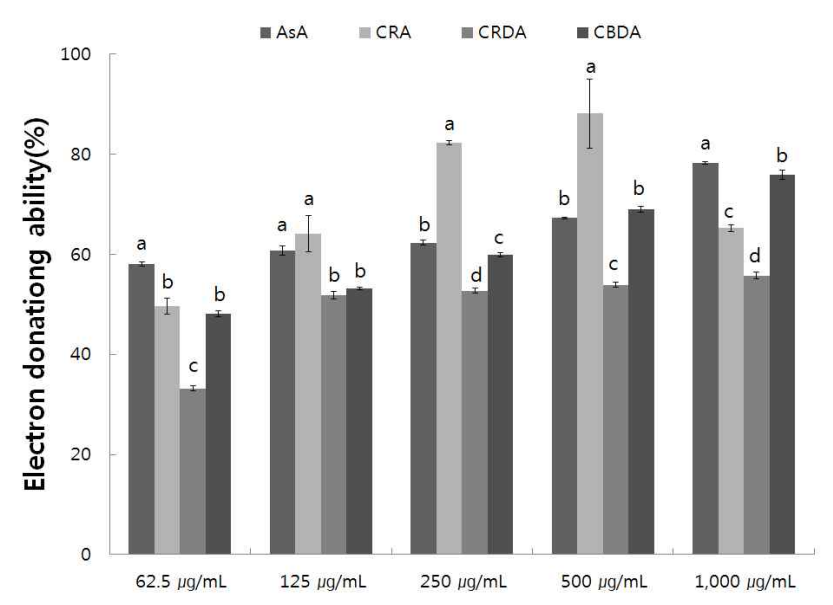

Fig. 2. Electron donating ability of ethanol extracts from cultivated Aster scaber.

CRA, Aster scaber cultivated in the farm field; CRDA, Aster scaber cultivated in the farm field, and dried at $25^{\circ} \mathrm{C}$; CBDA, Aster scaber cultivated in the farm field, and dried at $25^{\circ} \mathrm{C}$ after blanching. All values are expressed as mean $\pm \mathrm{SD}$ of triplicate determinations. Different letters indicate significantly different at $p<0.05$ by Duncan's multiple range test.

\section{SOD 유사활성능}

$\mathrm{SOD}$ 유사활성능 측정은 식품의 산화방지와 인간의 노화 억제와도 밀접한 관계가 있는 것으로 알려져 있으므로 산화 효소인 pyrogallol과 야생 및 재배의 생채, 자연건조 및 블랜 칭 건조 참취에 $70 \%$ 에탄올 추출물을 반응시켜 측정한 결과는 Fig. 3, 4에 나타내었다.

야생 생채, 자연건조 및 블랜칭 건조 참취의 $70 \%$ 에탄올 
추출물을 농도에 따라 SOD 유사활성능을 측정한 결과는 Fig. 3과 같다. 추출물의 농도가 증가함에 따라 SOD 유사활 성능 $1,000 \mu \mathrm{g} / \mathrm{mL}$ 의 농도에서 야생 생채, 자연건조 및 블랜 칭 건조 참취 추출물이 각각 $26.01,25.64,26.74 \%$ 의 SOD 유사활성능을 보여 야생 참취 건조 방법에 따른 SOD 유사 활성능은 큰 차이를 보이지 않았다.

재배 생채, 자연건조 및 블랜칭 건조 참취의 $70 \%$ 에탄올 추출물의 농도에 따라 SOD 유사활성능을 측정한 결과는 Fig. 4 와 같다. 아생 참취 추출물 결과와 유사하게 추출물의 농도가 증가할수록 SOD 유사활성능은 증가함을 보였고, $1,000 \mu \mathrm{g} / \mathrm{mL}$ 의 농도에서는 참취 추출물의 모든 군은 $20 \%$ 이상의 SOD 유사활성능을 보였고, 다른 군에 비해 블랜칭

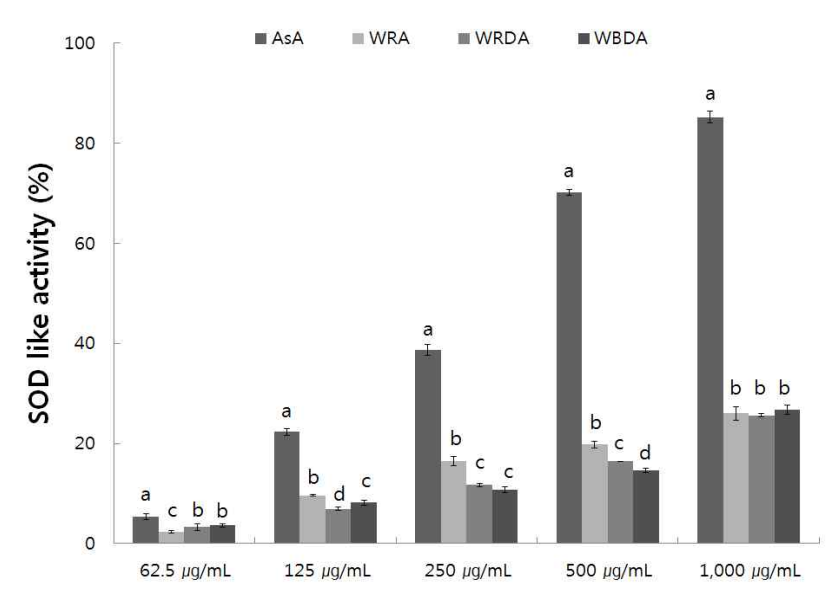

Fig. 3. SOD like activity of ethanol extracts from wild Aster scaber. WRA, Aster scaber grow in the wild; WRDA, Aster scaber grow in the wild, and dried at $25^{\circ} \mathrm{C}$; WBDA, Aster scaber grow in the wild, and dried at $25^{\circ} \mathrm{C}$ after blanching. All values are expressed as mean \pm SD of triplicate determinations. Different letters indicate significantly different at $\mathrm{p}<0.05$ by Duncan's multiple range test.

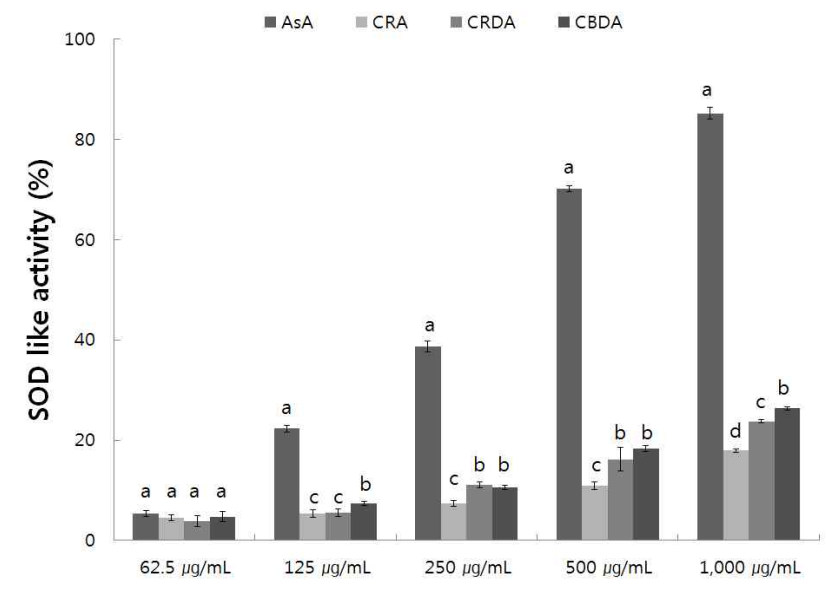

Fig. 4. SOD like activity of ethanol extracts from cultivated Aster scaber.

CRA, Aster scaber cultivated in the farm field; CRDA, Aster scaber cultivated in the farm field, and dried at $25^{\circ} \mathrm{C}$; CBDA, Aster scaber cultivated in the farm field, and dried at $25^{\circ} \mathrm{C}$ after blanching. All values are expressed as mean $\pm \mathrm{SD}$ of triplicate determinations. Different letters indicate significantly different at $\mathrm{p}<0.05$ by Duncan's multiple range test.
건조 참취 에탄올 추출물에서 높은 SOD 유사활성능을 보 였다.

\section{아질산염 소거능}

야생 및 재배 참취의 $70 \%$ 에탄올 추출물의 아질산염 소거능을 $\mathrm{pH} 1.2$ 에서 측정한 결과는 Fig. 5, 6과 같다.

야생 참취 에탄올 추출물의 아질산염 소거능 측정 결과 는 Fig. 5 와 같으며 야생 생채, 자연건조 및 블랜칭 건조 참취의 에탄올 추출물 $\mathrm{pH} 1.2$ 에서의 아질산염 소거능은 추출물의 농도가 증가함에 따라 아질산염 소거능이 증가하 였다. 야생 생채, 자연건조 및 블랜칭 건조 참취 에탄올 추출물 $1,000 \mathrm{\mu g} / \mathrm{mL}$ 의 농도에서 각각 $31.11,21.15,26.50 \%$ 로 생채, 블랜칭 건조, 자연건조 참취 추출물 순으로 아질산 염 소거능을 보였다.



Fig. 5. Nitrite scavenging ability of ethanol extracts from wild Aster scaber.

WRA, Aster scaber grow in the wild; WRDA, Aster scaber grow in the wild, and dried at $25^{\circ} \mathrm{C}$; WBDA, Aster scaber grow in the wild, and dried at $25^{\circ} \mathrm{C}$ after blanching. All values are expressed as mean $\pm \mathrm{SD}$ of triplicate determinations. Different letters indicate significantly different at $\mathrm{p}<0.05$ by Duncan's multiple range test.

재배 참취의 에탄올 추출물의 아질산염 소거능 측정 결 과는 Fig. 6과 같으며 $\mathrm{pH} 1.2$ 에서의 아질산염 소거능은 야생 과 같이 농도가 증가함에 따라 아질산염 소거능이 증가하였 다. 재배 생채, 자연건조 및 블랜칭 건조 참취의 에탄올 추출물 $1,000 \mu \mathrm{g} / \mathrm{mL}$ 농도에서 각각 $29.29,20.50,24.15 \%$ 의 아질산염 소거능을 보여 생채 참취 에탄올 추출물에서 다소 높은 아질산염 소거능을 확인할 수 있었다.

질산염이 많이 함유된 식품을 다량 섭취하면 아질산염과 제 2 급 및 제 3 급 아민의 nitroso화 반응이 위장내의 낮은 산성조건에서 쉽게 일어나서 발암물질인 nitrosamine을 생 성한다. Caffeic acid, ferulic acid 등의 phenolic acids와 catechol 등의 phenol류 그리고 ascorbic acid와 erythorbic $\mathrm{acid}$ 와 같은 환원물질이 아질산염과 반응하게 되면 nitrosamine의 생성을 저해할 수 있다(31). 따라서 야생 및 재배 참취의 추출물은 $\mathrm{pH} 1.2$ 에서 아질산염 소거능이 높아 nitrosamine 생성 저해에 효과가 있을 것으로 판단된다. 


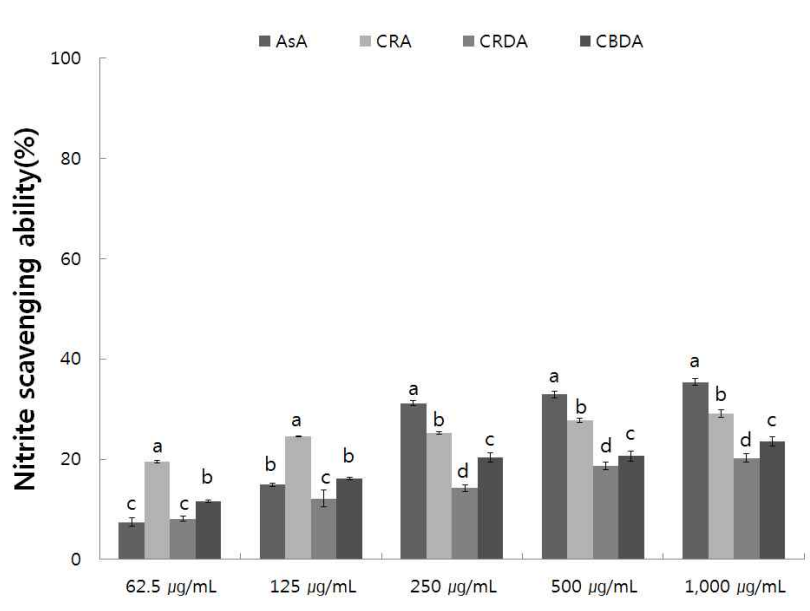

Fig. 6. Nitrite scavenging ability of ethanol extracts from cultivated Aster scaber.

CRA, Aster scaber cultivated in the farm field; CRDA, Aster scaber cultivated in the farm field, and dried at $25^{\circ} \mathrm{C}$; CBDA, Aster scaber cultivated in the farm field, and dried at $25^{\circ} \mathrm{C}$ after blanching. All values are expressed as mean $\pm \mathrm{SD}$ of triplicate determinations. Different letters indicate significantly different at $p<0.05$ by Duncan's multiple range test.

\section{Xanthine oxidase 저해 활성}

Xanthine oxidase는 생체 내 urine 대사에 관여하는 효소 로 xanthine 혹은 hypoxanthine으로 부터 urea를 형성하여 혈장 내 urea가 증가되면 낮은 용해성으로 인하여 골격에 축척되어 심한 통증을 유발하는 통풍(gout)을 일으킨다. 그 리하여 xanthine oxidase에 대한 야생 및 재배 생채, 자연건 조 및 블랜칭 건조 참취에 $70 \%$ 에탄올 추출물의 저해활성 을 측정한 결과는 Fig. 7,8 과 같다.

야생 생채, 자연건조 및 블랜칭 건조 참취 에탄올 추출물 의 xanthine oxidase 저해활성 결과는 Fig. 7과 같으며, 야생 생채, 자연건조 및 블랜칭 건조 참취의 에탄올 추출물 125 $\mathrm{\mu g} / \mathrm{mL}$ 의 농도에서 각각 $21.86,8.61,17.90 \%$ 의 저해활성을 보였으며, 대조구인 ascorbic acid는 $13.11 \%$ 로 생채 및 블랜 칭 건조 참취 에탄올 추출물이 ascorbic acid에 비해 높은 xanthine oxidase 저해 활성을 보였다. $125,250,500 \mu \mathrm{g} / \mathrm{mL}$ 의 농도에서 야생 생채 참취 에탄올 추출물의 경우 ascorbic acid에 비해 높은 xanthine oxidase 저해 활성을 보여 기능성 이 우수할 것으로 판단된다. 또한 야생 생채, 자연건조 및 블랜칭 건조 참취는 에탄올 추출물의 농도가 증가할수록 요산의 생성량이 줄어들어 xanthine oxidase에 대한 저해활 성이 높아짐을 알 수 있었다.

재배 생채, 자연건조 및 블랜칭 건조 참취의 에탄올 추출 물의 xanthine oxidase 저해활성 결과는 Fig. 8과 같다. 재배 생채, 자연건조 및 블랜칭 건조 참취의 에탄올 추출물에서 는 야생 참취 에탄올 추출물의 결과와 비슷하게 농도가 증가할수록 xanthine oxidase에 대한 저해활성이 높아짐을 알 수 있었다. $250 \mu \mathrm{g} / \mathrm{mL}$ 의 추출물 농도에서 생채, 자연건조 및 블랜칭 건조 참취의 에탄올 추출물 각각 $30.74,36.61$,
$34.29 \%$ 의 xanthine oxidase 저해활성을 보였으며, 대조구인 ascorbic acid는 같은 농도에서 $23.63 \%$ 의 xanthine oxidase 저해 활성을 보여 재배 참취 에탄올 추출물은 ascorbic acid 에 비해 대체적으로 높은 xanthine oxidase 저해 활성을 보였다.

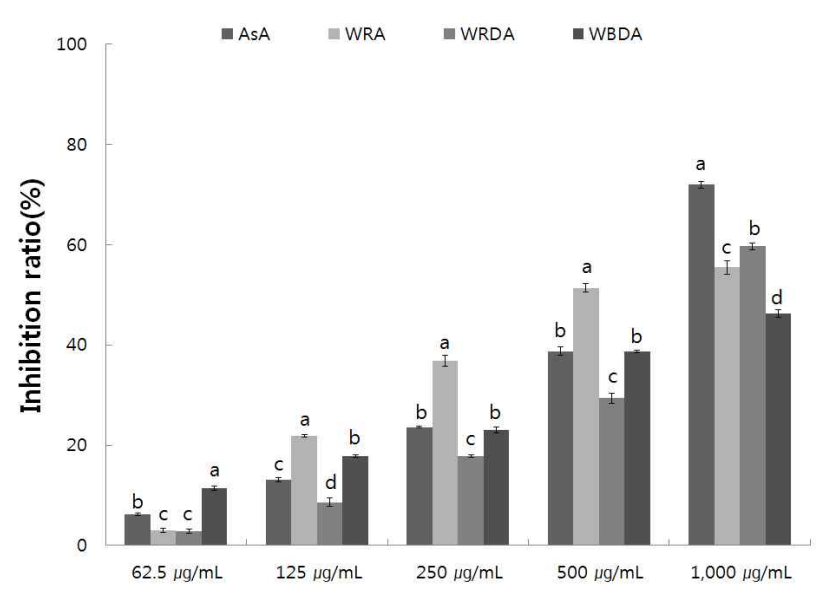

Fig. 7. Inhibition effect on the xanthine oxidase of ethanol extracts from wild Aster scaber.

WRA, Aster scaber grow in the wild; WRDA, Aster scaber grow in the wild, and dried at $25^{\circ} \mathrm{C}$; WBDA, Aster scaber grow in the wild, and dried at $25^{\circ} \mathrm{C}$ after blanching. All values are expressed as mean $\pm \mathrm{SD}$ of triplicate determinations. Different letters indicate significantly different at $\mathrm{p}<0.05$ by Duncan's multiple range test.

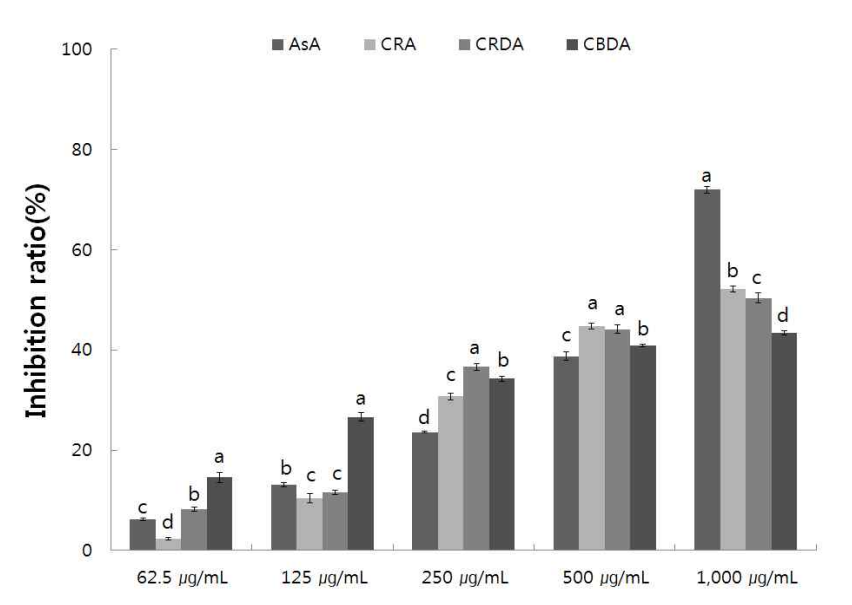

Fig. 8. Inhibition effect on the xanthine oxidase of ethanol extracts from cultivated Aster scaber.

CRA, Aster scaber cultivated in the farm field; CRDA, Aster scaber cultivated in the farm field, and dried at $25^{\circ} \mathrm{C}$; CBDA, Aster scaber cultivated in the farm field, and dried at $25^{\circ} \mathrm{C}$ after blanching. All values are expressed as mean $\pm \mathrm{SD}$ of triplicate determinations. Different letters indicate significantly different at $p<0.05$ by Duncan's multiple range test.

이상의 결과로 야생 및 재배 참취의 에탄올 추출물은 앞에서 연구한 폴리페놀 함량 결과에서 폴리페놀 함량이 높아 통풍의 예방 또는 생약 치료제의 개발 및 이용이 가능 할 것으로 사료된다. 


\section{Tyrosinase 저해 활성}

야생 및 재배의 생채, 자연건조 및 블랜칭 건조 참취의 에탄올 추출물의 tyrosinase 저해활성을 측정한 결과는 Fig. 9,10 과 같다.

야생 참취의 에탄올 추출물의 tyrosinase 저해활성 측정 결과는 Fig. 9와 같으며, 추출물의 농도가 증가할수록 저해 활성이 높아졌다. 야생 자연건조 참취의 tyrosinase 저해활 성은 다른 추출물에 비해 낮은 농도에서도 높은 활성을 보였으며, $62.5 ~ 500 \mathrm{\mu g} / \mathrm{mL}$ 의 농도에서는 대조구인 ascorbic acid 보다 활성이 더 높음을 알 수 있었다.

재배 참취 에탄올 추출물의 tyrosinase 저해활성 측정 결

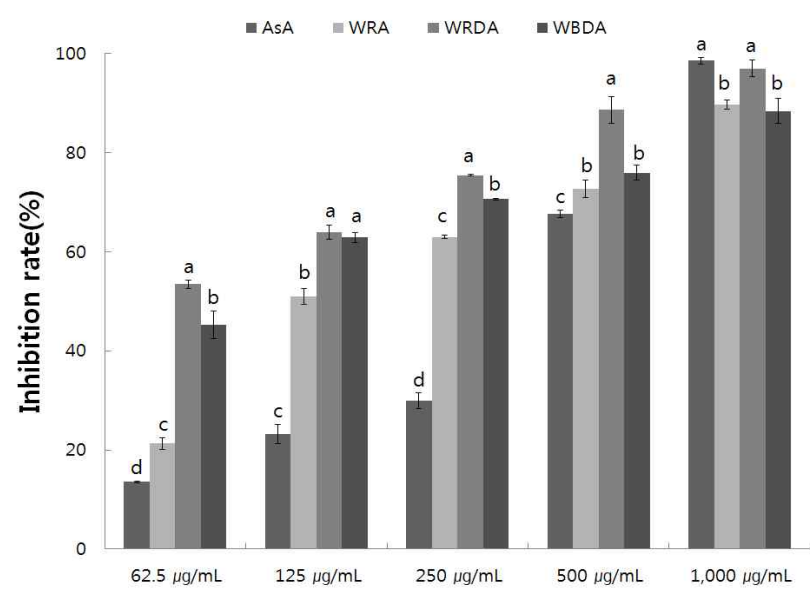

Fig. 9. Inhibition effect on the tyrosinase of ethanol extracts from wild Aster scaber.

WRA, Aster scaber grow in the wild; WRDA, Aster scaber grow in the wild, and dried at $25^{\circ} \mathrm{C}$; WBDA, Aster scaber grow in the wild, and dried at $25^{\circ} \mathrm{C}$ after blanching. All values are expressed as mean \pm SD of triplicate determinations. Different letters indicate significantly different at $\mathrm{p}<0.05$ by Duncan's multiple range test.

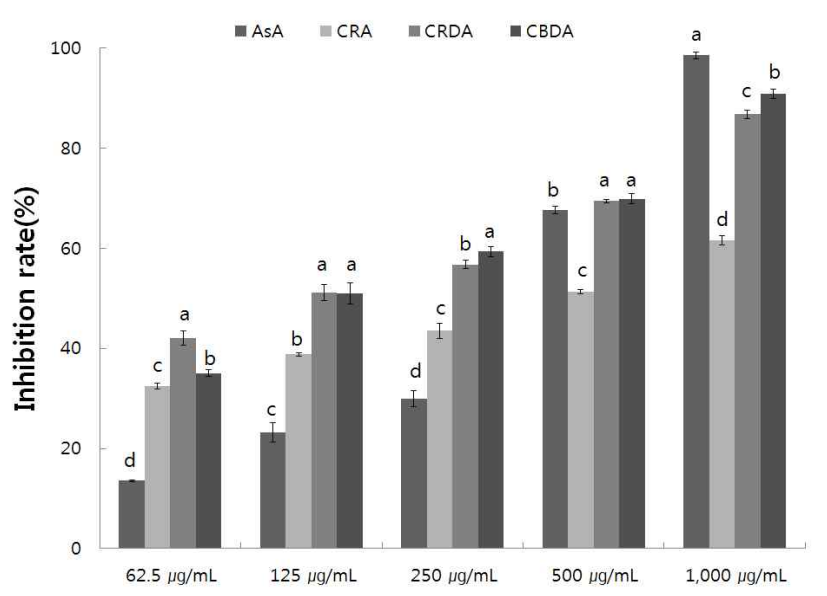

Fig. 10. Inhibition effect on the tyrosinase of ethanol extracts from cultivated Aster scaber.

CRA, Aster scaber cultivated in the farm field; CRDA, Aster scaber cultivated in the farm field, and dried at $25^{\circ} \mathrm{C}$; CBDA, Aster scaber cultivated in the farm field, and dried at $25^{\circ} \mathrm{C}$ after blanching. All values are expressed as mean $\pm \mathrm{SD}$ of triplicate determinations. Different letters indicate significantly different at $p<0.05$ by Duncan's multiple range test.
과는 Fig. 10 과 같으며, 야생 참취 에탄올 추출물의 결과와 유사하게 농도가 증가할수록 tyrosinase에 대한 저해활성이 높아짐을 알 수 있었다. 재배 블랜칭 건조 참취 추출물의 경우 $250 \mu \mathrm{g} / \mathrm{mL}$ 의 농도 이상에서는 생채와 자연건조 참취 에 비해 tyrosinase 저해활성이 높았다. 대체적으로 야생 참취가 재배 참취보다 tyrosinase 저해활성이 높게 나타 났다.

Tyrosinase는 멜라닌 합성 경로의 초기속도 결정단계에 관여하는 효소로 멜라닌이 과잉 생산되면 색소가 침착되어 피부손상을 초래하는 것으로 알려져 있기 때문에 멜라닌의 생성을 억제하기 위하여 tyrosinase의 활성을 저해하는 것이 중요하다(32). 본 실험 결과 야생 및 재배 참취 추출물의 경우 낮은 농도에서도 높은 tyrosinase 저해활성을 보여 멜 라닌 생성을 억제하기 위해 tyrosinase 활성을 저해할 것으 로 생각된다.

\section{환원력}

야생 및 재배의 생채, 자연건조, 블랜칭 건조 참취의 $70 \%$ 에탄올 추출물의 환원력을 측정한 결과는 Table 3 과 같으 며, 대조구로서는 BHT를 사용하였다.

야생 생채, 자연건조, 블랜칭 건조 참취의 에탄올 추출물 은 농도가 증가함에 따라 환원력은 증가함을 보였고, 1,000 $\mu \mathrm{g} / \mathrm{mL}$ 의 농도에서는 생채, 자연건조 및 블랜칭 건조 참취의 환원력이 각각 $1.48,0.60,1.00$ 으로 생채, 블랜칭 건조, 자연 건조 참취 순으로 에탄올 추출물에서 높은 환원력을 확인 할 수 있었다.

재배 생채, 자연건조, 블랜칭 건조 참취의 $70 \%$ 에탄올 추출물에 대한 환원력을 측정한 결과는 Table 5 와 같다. 재배 생채, 자연건조, 블랜칭 건조 참취의 에탄올 추출물은 농도가 증가함에 따라 추출물 모두 환원력이 증가함을 보였 고, $62.5 \mathrm{\mu g} / \mathrm{mL}$ 의 농도에서 재배 생채, 자연건조, 블랜칭 건조 참취는 각각 $0.11,0.12,0.13$ 으로 비슷한 환원력을 보였으며, $1,000 \mathrm{\mu g} / \mathrm{mL}$ 의 농도에서는 각각 $0.84,1.07,1.07$ 으로 환원력을 보여 블랜칭 건조 참취의 에탄올 추출물에서 환원력이 높았다.

시료 중에 항산화제와 같이 환원력을 가진 성분이 존재 하게 되면 $\mathrm{Fe}^{3+} / \mathrm{ferricyanide} \mathrm{complex}$ 를 $\mathrm{Fe}^{2+}$ 상태로 환원시키 면서 푸른색을 띠게 되는데(33), 흡광도 수치 자체가 시료의 환원력을 나타내므로 발색정도가 높을수록 높은 환원력을 나타낸다고 할 수 있다. Chung 등(34)의 연구 결과 구절초 추출물의 환원력 결과 $0.5 \mathrm{mg} / \mathrm{mL}$ 농도에서 $0.14 ~ 0.17,1.0$ $\mathrm{mg} / \mathrm{mL}$ 농도에서 0.24 0.27로 나타난 결과와 비교해 보면 야생 및 재배 참취 에탄올 추출물의 환원력은 높게 측정되 어 항산화 효과가 우수함을 확인 할 수 있었다. 
Table 3. Reducing power of ethanol extracts from Aster scaber

(Absorbance at $700 \mathrm{~nm}$ )

\begin{tabular}{cccccc}
\hline \multirow{2}{*}{ Samples $^{1)}$} & \multicolumn{5}{c}{ Reducing power $(\mu \mathrm{g} / \mathrm{mL})$} \\
\cline { 2 - 6 } & 62.5 & 125 & 250 & 500 & 1,000 \\
\hline WRA & $0.14 \pm 0.00 \mathrm{~b}^{3)}$ & $0.22 \pm 0.01^{\mathrm{b}}$ & $0.43 \pm 0.01^{\mathrm{b}}$ & $0.85 \pm 0.01^{\mathrm{b}}$ & $1.48 \pm 0.03^{\mathrm{b}}$ \\
WRDA & $0.01 \pm 0.00^{\mathrm{g}}$ & $0.12 \pm 0.00^{\mathrm{e}}$ & $0.21 \pm 0.00^{\mathrm{f}}$ & $0.34 \pm 0.01^{\mathrm{f}}$ & $0.60 \pm 0.05^{\mathrm{f}}$ \\
WBDA & $0.08 \pm 0.00^{\mathrm{f}}$ & $0.15 \pm 0.00^{\mathrm{d}}$ & $0.27 \pm 0.01^{\mathrm{d}}$ & $0.54 \pm 0.00^{\mathrm{d}}$ & $1.00 \pm 0.01^{\mathrm{d}}$ \\
CRA & $0.11 \pm 0.00^{\mathrm{e}}$ & $0.15 \pm 0.01^{\mathrm{d}}$ & $0.23 \pm 0.00^{\mathrm{e}}$ & $0.43 \pm 0.01^{\mathrm{e}}$ & $0.84 \pm 0.01^{\mathrm{e}}$ \\
CRDA & $0.12 \pm 0.00^{\mathrm{d}}$ & $0.18 \pm 0.00^{\mathrm{c}}$ & $0.31 \pm 0.02^{\mathrm{c}}$ & $0.60 \pm 0.01^{\mathrm{c}}$ & $1.07 \pm 0.02^{\mathrm{c}}$ \\
CBDA & $0.13 \pm 0.00^{\mathrm{c}}$ & $0.21 \pm 0.02^{\mathrm{b}}$ & $0.32 \pm 0.00^{\mathrm{c}}$ & $0.60 \pm 0.02^{\mathrm{c}}$ & $1.07 \pm 0.02^{\mathrm{c}}$ \\
BHT $^{2)}$ & $0.27 \pm 0.00^{\mathrm{a}}$ & $0.57 \pm 0.01^{\mathrm{a}}$ & $0.88 \pm 0.01^{\mathrm{a}}$ & $1.36 \pm 0.01^{\mathrm{a}}$ & $1.53 \pm 0.04^{\mathrm{a}}$ \\
\hline
\end{tabular}

${ }^{1)}$ WRA, Aster scaber grow in the wild; WRDA, Aster scaber grow in the wild, and dried at $25^{\circ} \mathrm{C}$; WBDA, Aster scaber grow in the wild, and dried at $25^{\circ} \mathrm{C}$ after blanching CRA, Aster scaber cultivated in the farm field; CRDA, Aster scaber cultivated in the farm field, and dried at $25^{\circ} \mathrm{C}$, CBDA; Aster scaber cultivated in the farm field, and dried at $25^{\circ} \mathrm{C}$ after blanching.

${ }^{2)}$ BHT, butylated hydroxy toluene.

${ }^{3)}$ All values are expressed as mean $\pm \mathrm{SD}$ of triplicate determinations. Different letters indicate significantly different at $\mathrm{p}<0.05$ by Duncan's multiple range test.

\section{요 약}

본 연구는 산지에 자생하는 참취와 밭에서 재배하는 참 취의 품질과 기능성을 평가하기 위하여 에탄올 추출물의 항산화 물질 및 항산화성에 대하여 조사하였다. 참취의 에 탄올 추출물의 수율은 블랜칭 건조한 시료에서 높았고, 폴 리페놀 함량은 야생 및 재배 블랜칭 건조한 시료에서 각각 $35.59,26.83 \mathrm{mg} / \mathrm{g}$ 으로 야생 조에서 높은 함량을 보였다. 전자공여능은 농도가 증가함에 따라 모든 군에서 활성이 증가했고 블랜칭 건조가 가장 높은 전자공여능을 보였다. $\mathrm{SOD}$ 유사활성능은 야생 참취는 생채에서 높은 활성을 보 였고, 재배 참취는 블랜칭 건조에서 높았다. 아질산염 소거 능 $\mathrm{pH} 1.2$ 에서는 생채와 재배 추출물의 농도가 높을수록 높은 소거능을 보였고, 재배보다 생채 참취 추출물이 더 높았다. Xanthine oxidase 저해효과, tyrosinase 저해효과 측 정 결과에서는 추출물의 농도가 증가할수록 저해효과가 높았으며 야생 참취에서 높은 저해활성을 보였다. 환원력 은 추출물의 농도가 증가함에 따라 환원력은 증가함을 보였 고 블랜칭 건조가 높은 환원력을 보였으며 야생 참취 추출 물에서 높은 환원력을 나타내었다. 이상의 결과에서 참취 에탄올 추출물의 항산화 활성은 재배 참취의 추출물에 비해 야생 참취의 추출물에서 높았다. 참취 추출물의 항산화 활 성은 생채 및 블랜칭 건조 참취 추출물의 항산화 활성이 자연건조 참취 추출물에 비해 전반적으로 높았다. 따라서 참취는 영양성과 항산화 활성이 우수하여 항산화 및 노화 예방에 우수한 식품이며, 참취를 이용한 다양한 가공식품 의 개발은 국민 건강과 더불어 참취의 소비확대 및 부가가 치 창출에 이바지할 수 있을 것으로 기대된다.

\section{감사의 글}

본 연구는 대구한의대학교 기린연구비 지원(2012-901-41) 에 의해 수행된 연구의 일부이며, 이에 감사드립니다.

\section{References}

1. Kim HK, Kwon YJ, Kim YE, Nahmgung B (2004) Changes of total polyphenol content and antioxidant activity of Aster scaber Thunb extracts with different microwave-assisted extraction conditions. Korean J Food Preserv, 11, 88-93

2. Nam GS, Lee HI, Lee JY, Kim MS (1994) Studies of recognition, interest and consumption to nature food of homemaker. J Soc Diet Life Cult, 9, 116-124

3. Kim MS (1986) A historical study on the utilization of wild vegetables. Korean J Diet Cult, 1, 167-170

4. Hedrich S, Lee KW, Xu X, Wan HJ, Murphy PA (1994) Defining food components as new nutrients. J Nutr, 124, 1789-1792

5. Choi HS, Kim MSL, Sawamura M (2001) Constituents of the essential oil of Angelica tenuissima an aromatic medicinal plant. Food Sci Biotechnol, 10, 557-561

6. Hiruma-Lima CA, Gracioso JS, Bighetti EJB, Grassi-Kassisse D, Nunes DS, Souza-Brito ARM (2002) Effect of essential oil obtained from Croton cajucara Benth on gastric ulcer healing and protective factors of the gastric mucosa. Phytomedicine, 9, 523-529

7. Caldefied-Chezet F, Zet M, Guerry J, Chalchat C, Fusiller 
M, Vasson (2004) Anti-inflammatory effects of Melaleuca alternifolia essential oil on human polymorphonuclear neutrophils and monocytes. Free Radic Res, 38, 805-811

8. Lee KH, Rhee KH (2010) Anti-inflammatory effects of Glycyrrhiza glabra Linne extract in a dextran sulfate sodium-induced colitis ouse model. Korean J Food Nutr, 23, 435-439

9. Kang HS, You HC, Choi UR, Kim HK, Jo SM, Yoon BJ (2011) Effect of Smilax china L. rhizome extract on heavy metal contents in rats. Korean J Food Nutr, 24, 233-238

10. Yok CS (1989) Color wild medical pant in Korea. Academy press, Seoul, p 3

11. Kim TJ (2008) Wild flowers and resource plant in Korea. Seoul, University press, Seoul, p 43

12. Mun JH (2007) Solid matrix priming improves seed germinability of Korean aster (Aster scaber Thunb.). MS Thesis. Gyeongsang National University, Korea

13. Jeon SM, Lee JY, Kim HW, Lee YM, Jang HH, Hwang KA, Kim HR, Park DS (2012) Antioxidant activity of extracts and fractions from Aster scaber. J Korean Soc Food Sci Nutr, 41, 1197-1204

14. Park CB, Gang, YG, Ahn TJ, Kim GS, Han SH (2011) The evolution of wild mountain herb industry : high added value of wild plant for 21 century, RDA Interobang, 14, $1-25$

15. Seo JT, You DL, Joung JC, Kim WB, Kim JH (2012) Message of spring, wild edible mountain herbs : for utilization by pass taste and flavor, RDA Interobang, $61,1-18$

16. Singleton VL, Rossi A (1965) Colorimetry of total phenolics with phosphomolybdic phosphotungstic acid reagents. Am J Enol Viticult, 16, 144-158

17. Moreno VL, Isla MI, Sampietro AR, Vattuone MA (2000) Comparison of the free radical-scavenging activity of propolis from several regions of Argentina. J Ethnopharmacol, 71, 109-114

18. Blois ML (1958) Antioxidant determination by the use of a stable free radical. Nature, 181, 1199-1224

19. Marklund S, Marklund G (1974) Involvement of the superoxide anion radical in the autoxidation of pyrogallol and a convenient assay for superoxide dismutase. Eur J Biochem, 47, 469-474

20. Kato H, Lee IE, Chuyen NV, Kim SB, Hayase F (1987) Inhibitory of nitrosamine formation by nondilyzable melanoidins. Agric Biol Chem, 51, 1333-1338
21. Stirpe F, Corte ED (1969) The regulation of rat liver xanthine oxidase. J Biol Chem, 244, 3855-3861

22. Yagi A, Kanbara T, Morinobu N (1987) The effect of tyrosinase inhibition by aloe extract. Planta Medica, 53, 515-517

23. Wong JY, Chye FY (2009) Antioxidant properties of selected tropical wild edible mushrooms. J Food Comp Anal, 22, 269-277

24. Park WP (2014) Quality characteristics of noodles added with Houttuynia cordata Thunb powder. Korean J Food Preserv, 21, 34-39

25. Roberfroid MB, Van Loo JA, Gibson GR (1998) The bifidogenic nature of chicory insulin and its hydrolysis products. J Nutr 128, 11-19

26. Park CK, Cha JY, Jeon BS, Kim NM, Shim KH (2000) Effects of chicory root water extracts on serum triglyceride and mitriglyceride transfer protein (MTP) activity in rats. J Korean Soc Food Sci Nutr, 29, 518-524

27. Choi JH, Park YH, Lee IS, Lee SP, Yu MH (2013) Antioxidant activity and inhibitory effect of Aster scaber Thunb extract on adipocyte differentiation in 3T3-L1 cells. Korean J Food Sci Technol, 45, 356-363

28. Jeon SM, Lee JY, Kim HW, Lee YM, Jang HH, Hwang KA, Kim HR, Park DS (2012) Antioxidant activity of extracts and fractions from Aster scaber. J Korean Soc Food Sci Nutr, 41, 1197-1204

29. Lee YM, Bae JH, Jung HY, Kim JH, Park DS (2011) Antioxidant activity in water and methanol extracts from Korean edible wild plants. J Korean Soc Food Sci Nutr, 40, 29-36

30. Torel J, Gillard J, Gillard P (1986) Antioxidant activity of flavonoids and reactivity with peroxy radical. Phytochem, 25, 383-38

31. Gray JI, Dugan JLR (1975) Inhibition of N-nitrosamine formation in model food system. J Food Sci, 40, 981-985

32. Lerch K (1978) Amino acid sequence of tyrosinase from Nurospora crassa. Proc Natl Acad Sci, 75, 3635-3539

33. Gulcin I, Berashvili G, Gepdiremen A (2005) Antiradical and antioxidant activity of total anthocyanins from Perilla nankinensis decne. J Ethmopharmacol, 101, 287-293

34. Chung HJ, Jeon IS (2011) Antioxidative activities of methanol extracts from different parts of Chrysanthemum zawadskii. Korean J Food Preserv, 18, 739-745 